\title{
IDENTIFICATION OF CAREER CHOICE MOTIVATIONS IN MEDICAL STUDENTS AND ITS ASSOCIATION WITH ACADEMIC PERFORMANCE AND GENDER; A CASE CONTROL STUDY
}

\author{
Faiza Kiran, Shazia Irum*, Asiya Zahoor** \\ Army Medical College/National University of Medical Sciences (NUMS) Rawalpindi Pakistan, *Shifa College of Medicine, Islamabad Pakistan, **National \\ University of Medical Sciences (NUMS), Rawalpindi Pakistan
}

\begin{abstract}
Objective: To identify the reasons for choosing medicine as a career in medical students and find their association with gender and different academic performance.

Study Design: Case control study.

Place and Duration of Study: Shifa College of Medicine, Islamabad Pakistan, from 2015 to 2017.

Methodology: A self-reported questionnaire was developed after thorough literature search and interviewing few students. All students who gave consent and filled questionnaire were included in the study. Students, who obtained less than $50 \%$ marks in professional examinations, were labelled as cases and those who passed were labelled as controls. Ratio of cases to controls obtained was 1:2. Data was analyzed using SPSS-23.

Results: Total 225 students took part in the study. Half of both genders [M=55 (50\%), F=61 (53\%)] came into this field by their own choice. Male students chose medicine as a career mainly because they were more passionate $[\mathrm{M}=51(46 \%), \mathrm{F}=38(33 \%), p$ value $=0.03]$, wanted to honor their parents' wishes $[\mathrm{M}=35(31 \%), \mathrm{F}=28(24 \%)]$, and used to find biology easier than math $[\mathrm{M}=19(17 \%), \mathrm{F}=14(12 \%)]$. Female students chose medicine as a career mainly because they had a misconception of relatively easier career growth in medicine $[\mathrm{M}=4(3 \%), \mathrm{F}=6(5 \%)]$.

Conclusion: Most medical students in this private institute came into medicine of their own choice. However, passion, honoring parents' wishes and finding biology easier than math was more evident in failed students and male gender whereas females came with misconception of an easy career path in medicine.
\end{abstract}

Keywords: Academic performance, Case control study, Demographic characteristics, Medical students.

This is an Open Access article distributed under the terms of the Creative Commons Attribution License (https://creativecommons.org/licenses/by-nc/4.0/), which permits unrestricted use, distribution, and reproduction in any medium, provided the original work is properly cited.

\section{INTRODUCTION}

Various personal and environmental factors influence career choice amongst students in healthcare fields ${ }^{1}$. Selection of medicine as a career by adolescents has been extensively studied over decades, collecting informative evidence for making educational policies. School-age students are attracted to healthcare related fields due to certain career attributes namely, altruism, job stability, professional prestige, job autonomy and familial influences ${ }^{2,3}$. Parental support in cultural, social, and academic context plays a vital role on career selection, growth, and motivation of youth ${ }^{4}$. In developing world, intrinsic motivation, intellectual curiosity, death and illness of family/friends, social prestige and financial gain were considered as main triggers leading to choosing medicine as a career ${ }^{5,6}$. In Southeast Asian countries, family influence and indoctrination also push students toward medicine?.

Career choice also involves intrinsic and extrinsic factors for motivation ${ }^{8}$. Various studies indicate internal motivation influences learning process and acade-

Correspondence: Dr Faiza Kiran, Department of Medical Education, Army Medical College Rawalpindi Pakistan

Received: 28 Oct 2020; revised received: 12 Jan 2020; accepted: 23 Feb 2021 mic performance ${ }^{9,10}$. The objective of this study was to identify the reasons for choosing medicine as a career in medical students and find its association with gender and different academic performance.

\section{METHODOLOGY}

After obtaining approval from ethical committee and Institutional Review Board, IRB \# 442-291-2015, a non-interventional, case control study was conducted in a private medical college of Pakistan in Islamabad from 2015 to 2017. Initially, few failed students were interviewed and were asked open-ended question, "why do you think, you chose medicine as a career?". Students' identity was kept anonymous which gave them confidence to reflect and analyze their motivations. A thorough literature search was done, and a questionnaire was developed which was pilot tested on the same 15 students. Based on their feedback, the questionnaire was modified. The final questionnaire consisted of list of 7 reasons of choosing medicine as a career, requiring answers in a Yes or No format. Questionnaire was distributed to all cases, studying currently, in each year of medical college via purposive sampling technique. Controls were selected at random from corresponding year cohorts using a ratio of 2 
controls for each case ${ }^{11}$. Students, who obtained $<50 \%$ marks in professional examinations, even once in their 5 year tenure, gave consent, and filled the questionnaire were labeled as cases whereas all those who obtained more than $50 \%$ marks, gave consent, and filled the questionnaire were labeled as controls. Those who were reluctant and did not give consent were excluded. Students' names and roll numbers were not asked to keep anonymity. Questionnaires filled inappropriately were discarded. In three years, data from 75 cases and 150 controls was taken. Data was analyzed using SPSS-23. Odds ratio was calculated to observe relative risk of underperformance in the struggling students. Chi square test was also applied to observe difference in responses of both genders and those studying in different academic years; significance value was $\leq 0.05$ for statistical analyses.

\section{RESULTS}

Out of 225 students who took part in this study, 75 were cases and 150 were controls. It was evident from table-I, that only 39 (52\%) failed students chose medicine of their own choice, $36(48 \%)$ said it was their passion $(\mathrm{RR}=1.689)$, whereas $24(32 \%)$ declared that it sion and their free will are reasons for choosing their career but more cases 35 (31\%) than controls 28 (24\%) claimed to be under influence of their parents' wishes.

Table-II showed that approximately Half of both genders $[\mathrm{M}=55(50 \%), \mathrm{F}=61(53 \%)]$ came into this field by their own choice. Male students chose medicine as a career mainly because they were more passionate [M=51 (46\%), $\mathrm{F}=38(33 \%), p$-value $=0.03]$, wanted to honor their parents' wishes [M=35 (31\%), F=28 (24\%)], and used to find biology easier than math $[\mathrm{M}=19$ $(17 \%), \mathrm{F}=14(12 \%)]$. Female students chose medicine as a career mainly because they had a misconception of relatively easier career growth in medicine $[\mathrm{M}=4(3 \%)$, $\mathrm{F}=6(5 \%)]$ whereas few were still confused about their purpose of choosing this field $[\mathrm{M}=5(4 \%), \mathrm{F}=8(7 \%)]$.

Two variables in case control study had higher significance value: passion of medicine $(p=0.046)$ and finding biology easier than math $(p=0.038)$. While sorting gender difference in their reason of choosing this career, being passionate about this field was the only variable found significant $(p=0.03)$; more male students had a passion for their field than female students $[\mathrm{M}=$ $51(46 \%), \mathrm{F}=38(33 \%)]$.

Table-I: Association of reasons for choosing medicine as a career to academic failure of medical students

\begin{tabular}{|c|c|c|c|c|}
\hline I chose Medicine as a Career Because & $\begin{array}{c}\text { Cases } \\
(\%)\end{array}$ & $\begin{array}{c}\text { Controls } \\
(\%)\end{array}$ & $\begin{array}{c}\text { Odds Ratio } \\
\text { Case/Controls }\end{array}$ & $\begin{array}{c}p \text {-value by Chi Square } \\
\text { Test }(p \leq 0.05)\end{array}$ \\
\hline I was passionate about it & $36(48 \%)$ & $53(35 \%)$ & 1.689 & 0.046 \\
\hline It was my own choice & $39(52 \%)$ & $77(51 \%)$ & 1.027 & 0.519 \\
\hline It was my parents' dream & $24(32 \%)$ & $39(26 \%)$ & 1.339 & 0.215 \\
\hline I had no other choice & $3(4 \%)$ & $15(10 \%)$ & 0.375 & 0.092 \\
\hline $\begin{array}{l}\text { I thought it would be easier to } \\
\text { continue career in medicine }\end{array}$ & $4(5 \%)$ & $6(4 \%)$ & 1.352 & 0.441 \\
\hline I used to find biology easier than math & $16(21 \%)$ & $17(11 \%)$ & 2.1 & 0.038 \\
\hline I do not know & $2(2.6 \%)$ & $11(7 \%)$ & 0.346 & 0.131 \\
\hline \multicolumn{5}{|c|}{ Table-II: Gender difference in career choice motivations. } \\
\hline \multicolumn{2}{|l|}{ I Chose Medicine as a Career Because } & $\begin{array}{c}\text { Male } \\
\mathrm{n}=111(\%)\end{array}$ & $\begin{array}{c}\text { Female } \\
n=114(\%)\end{array}$ & $\begin{array}{c}p \text {-value by Chi square } \\
\text { test }(p \leq 0.05)\end{array}$ \\
\hline \multicolumn{2}{|l|}{ I was passionate about it } & $51(46 \%)$ & $38(33 \%)$ & 0.036 \\
\hline \multicolumn{2}{|l|}{ It was my own choice } & $55(50 \%)$ & $61(53 \%)$ & 0.323 \\
\hline \multicolumn{2}{|l|}{ It was my parents' dream } & $35(31 \%)$ & $28(24 \%)$ & 0.155 \\
\hline \multicolumn{2}{|l|}{ I had no other choice } & $8(7 \%)$ & $10(9 \%)$ & 0.427 \\
\hline \multicolumn{2}{|c|}{ I thought it would be easier to continue career in medicine } & $4(3 \%)$ & $6(5 \%)$ & 0.391 \\
\hline \multicolumn{2}{|l|}{ I used to find biology easier than math } & $19(17 \%)$ & $14(12 \%)$ & 0.201 \\
\hline \multicolumn{2}{|l|}{ I don't know } & $5(4 \%)$ & $8(7 \%)$ & 0.302 \\
\hline
\end{tabular}

was their parents' dream $(R R=1.339)$. Few cases $4(5 \%)$ had a misconception that career in medicine is relatively easier than other fields ( $R R=1.352)$. The highest odds $(R R=2.1)$ for failing was their belief that biology is easier than math [cases=16 (21\%), control $\mathrm{s}=17(11 \%)$, $p=0.038$. Although failed students believed that pas-
Table-III shows an interesting trend. Passion for medicine has declined from first year $11(58 \%)$ to final year $12(39 \%)$ students. A fair number of students from all years of study [ $3^{\text {rd }}$ year $30(49 \%), 4^{\text {th }}$ year $12(57 \%)$, first, second $10(52 \%)$ and final year $16(52 \%)]$ proclaimed that they came into medicine of their free will. 
Students of $4^{\text {th }}$ year $4(19 \%)$ and final year $5(16 \%)$ recognized that their career choice motivation was finding biology easier than math. Main reason for choosing Medicine for first year students was their passion $11(58 \%)$. More than half of first year $48(52 \%)$ and nearly half of second-year students $30(49 \%)$ declared that they chose medicine with free will. Final year students $12(39 \%)$, proclaimed that their career choice was their parents' dream. Anecdotally, this may be because they are senior students and are bold enough to admit this. Moreover, they had a misconception that career continuing in medicine would be easier 4 (13\%). It was encouraging to note that by reaching final year, students had no ambiguity recognizing their reason for choosing medicine as a career.
Nearly half percentage of both genders [M=55 (50\%), $\mathrm{F}=61(53 \%), p=0.323$ ] claimed that they came into this field by their own choice but further evidence suggested that a significant number of male students declared that they chose medicine $[\mathrm{M}=35(31 \%), \mathrm{F}=28$ $(24 \%), p=0.155]$ to fulfill their parents 'dream which can be interpreted as indoctrination or parental pressure. This is in accordance with findings of Kiran and Javaid 7 and Gyorffee 15 who stated that meeting parental expectations and desire to make them happy were main motivations for students in some cases. This is endorsed by study findings of Kim et $\mathrm{al}^{6}$, where male students showed effect of doctor parents as the main reason. In contrast to study findings of Kim et $\mathrm{al}^{6}$, who stated that females chose medicine because of altruism,

Table-III: Career choice motivation in medical students in different year of study.

\begin{tabular}{|c|c|c|c|c|c|c|}
\hline $\begin{array}{l}\text { I Chose Medicine as a Career } \\
\text { Because }\end{array}$ & $\begin{array}{c}\text { Year } 1 \\
n=19(\%)\end{array}$ & $\begin{array}{c}\text { Year } 2 \\
\mathrm{n}=93(\%)\end{array}$ & $\begin{array}{c}\text { Year } 3 \\
n=61(\%)\end{array}$ & $\begin{array}{c}\text { Year } 4 \\
n=21(\%)\end{array}$ & $\begin{array}{c}\text { Year } 5 \\
n=31(\%)\end{array}$ & $\begin{array}{c}p \text {-value by Chi square } \\
\text { test }(p \leq 0.05)\end{array}$ \\
\hline I was passionate about it & $11(58 \%)$ & $35(38 \%)$ & $24(39 \%)$ & $7(33 \%)$ & $12(39 \%)$ & 0.530 \\
\hline It was my own choice & $10(52 \%)$ & $48(52 \%)$ & $30(49 \%)$ & $12(57 \%)$ & $16(52 \%)$ & 0.982 \\
\hline It was my parents' dream & $3(16 \%)$ & $27(29 \%)$ & $15(24 \%)$ & $6(28 \%)$ & $12(39 \%)$ & 0.467 \\
\hline I had no other choice & $1(5 \%)$ & $8(9 \%)$ & $5(8 \%)$ & $1(5 \%)$ & $3(10 \%)$ & 0.956 \\
\hline $\begin{array}{l}\text { I thought it would be easy to } \\
\text { continue career in medicine }\end{array}$ & $1(5 \%)$ & $3(3 \%)$ & $1(2 \%)$ & $1(5 \%)$ & $4(13 \%)$ & 0.152 \\
\hline $\begin{array}{l}\text { I used to find biology easier } \\
\text { than math }\end{array}$ & $2(11 \%)$ & $14(15 \%)$ & $8(13 \%)$ & $4(19 \%)$ & $5(16 \%)$ & 0.627 \\
\hline I do not know & $1(5 \%)$ & $6(6 \%)$ & $4(6 \%)$ & $2(10 \%)$ & - & 0.131 \\
\hline
\end{tabular}

\section{DISCUSSION}

Motivation is also one of the predictors of students' high GPA, persistence in a study program and their psychological well-being. Students whose career choice motivations included the illness/death of a relative, faced emotional exhaustion due to burnout than students with other motivations ${ }^{12,13}$.

There is significant feminization of medical profession in recent decades. Worldwide, $60 \%$ of medical students are now females. Evidence from developed world shows this emerging trend as females being internally motivated and altruistic than male students ${ }^{14}$. Further added fact was more interest and thus commitment of females in this profession since childhood. Motivational factor in male students was found to be prestige, following footsteps of parents, and meeting parental expectations ${ }^{15}$. In contrast, emerging demand of "doctor brides", in developing world, has forced many girls into medicine ${ }^{16}$.

Our study results showed unique findings of male students being more passionate for medicine [M= $51(46 \%), F=38(33 \%), p=0.036]$ than female students. our results indicated that female students had a misunderstanding that it would be easier to continue career in medicine $[\mathrm{M}=4(3 \%), \mathrm{F}=6(5 \%)]$, whereas few were still unclear about their motive to choose career in this field $[\mathrm{M}=5(4 \%), \mathrm{F}=8(7 \%)]$. This can be explained by the lack of career counselingin Pakistan and pushing of girls towards medicine as it gives them better marriage prospects. Moreover, a doctor bride is shown as a "trophy wife" in the society which raises value of this degree ${ }^{17}$.

This was a pre-liminary study into career choice motivation using a relatively small sample from one private institution. Therefore, future research with a larger sample size, from multiple institutions is warranted to enhance the generalizability of this study.

Medicine is a tremendously challenging career, provides a critical safeguard for human health and safety. This field is rather competitive and qualified students compete for admission to higher medical education institutions across the globe. As medical field is extremely tough and demanding, students must bring internal motivations for learning ${ }^{18,19}$. This will ensure 
better health care by providing society with safe, healthy, and committed physicians.

\section{CONCLUSION}

Multiple factors play vital roles in career selection varying in different contexts. Factors influencing career choice in Asian countries would not be same as that of students in European countries and vice versa. According to our study, highest odds of failing were for those whose motivations were finding biology easier than math. Failed students usually follow their parents' dream, though they also believed it was their passion and free will. More than half students, irrespective of gender, came into medicine of their own choice. However, passion, honoring parents' wishes and finding biology easier than math was more evident in males whereas females had a misconception that pursuing career in medicine is an easier path.

\section{CONFLICT OF INTEREST}

This study has no conflict of interest to be declared by any author.

\section{REFERENCES:}

1. Kodama CM, Huynh J. Academic, and career development: Rethinking advising for Asian American students. New Dir Stu Ser 2017; 2017(160): 51-63.

2. Liaw SY, Wu LT, Lopez V, Chow YL, Lim S, Holroyd E, et al. Development and psychometric testing of an instrument to compare career choice influences and perceptions of nursing among healthcare students. BMC Med Educ 2017; 17(1): 72-75.

3. Wu LT, Low MMJ, Tan KK, Lopez V, Liaw SY. Why not nursing. A systematic review of factors influencing career choice among healthcare students. Int Nurs Rev 2015; 62(4): 547-62.

4. Lim SA, You S. Long-term effect of parents' support on adolescents' career maturity. J Career Dev 2017; 46(1): 48-61.

5. Miah S, Venugopal S, Pang K, Rebello W, Rubakumar Z. What factors influence British medical students' career intentions? Location and social relationships. Med Teach 2015; 37(7): 703-708.

6. Kim KJ, Hwang JY, Kwon BS. Difference in medical students' academic interest and performance across career choice motiva- tions. Int J Med Educ 2016; 7(1): 52-55.

7. Kiran F, Javaid A. Students' perceptions of factors for academic failure in pre-clinical years of a medical school. J Pak Med Assoc 2020; 70(5): 803-808.

8. Miller AK, Osborn DS, Sampson Jr JP, Peterson GW, Reardon $\mathrm{RC}$. The impact of a college career course on students' career decision states. Career Development Quarterly 2018; 66(4): 371-77.

9. Gu X, Tang M, Chen S, Montgomery ML. Effects of a career course on chinese high school students' career decision making readiness. Career Dev Q 2020; 68(3): 222-37.

10. Kusurkar RA, Ten Cate TJ, van Asperen M, Croiset G. Motivation as an independent and a dependent variable in medical education: a review of the literature. Med Teach 2011; 33(5): e24262.

11. Yates J, James D. Predicting the "strugglers": a case-control study of students at Nottingham University Medical School. Br Med J 2006; 332(7548): 1009-13.

12. Baxter L, Mattick K, Kuyken W. Assessing health care students' intentions and motivations for learning: the Healthcare Learning and Studying Inventory (HLSI). Adv Health Sci Educ Theory Pract 2013; 18(3): 451-62.

13. Pagnin D, De Queiroz V, De Oliveira Filho MA, Gonzalez NV, Salgado AE, Cordeiro e Oliveira B, et al. Burnout and career choice motivation in medical students. Med Teach 2013; 35(5): 388-94.

14. Campbell A, Dennis A, Wilkinson T, McAleer S. The relationship between gender and career choice in medicine-an overview. J Gend Stud 2020: 29(7): 1-4.

15. Gyorffy Z, Birkas E, Sandor I. Career motivation and burn out among medical students in Hungary-could altruism be a protective factor. BMC Med Educ 2016; 16(1): 182-85.

16. Moazam F, Shekhani S. Why women go to medical college but fail to practice medicine: perspectives from the Islamic Republic of Pakistan. Med Educ 2018; 52(7): 705-15.

17. Iqbal $\mathrm{H}$. The doctor brides revolutionizing Pakistan's healthcare. Cited [31 Aug 2020). Available at Internet from: https://www. pioneerspost.com/news-views/20200323/the-doctor-bridesrevolutionising-pakistan-s-healthcare.

18. Alexander K, Cleland J, Nicholson S. Bridging the cultural divide? Exploring school pupils' perceptions of medicine. Med Educ 2019; 53(6): 571-83.

19. Kim YJ. Why to think carefully before pursuing a career in medicine. Cited [27 Aug 2020]. Available at: https://scopeblog. stanford.edu/2018/08/07/why-to-think-carefully-beforepursuing-a-career-in-medicine/. 